\title{
Making Sense of the Law and Society Movement
}

\author{
Daniel Blocq \& Maartje van der Woude*
}

\begin{abstract}
This article aims to deepen scholarly understanding of the Law and Society Movement (L\&S) and thereby strengthen debates about the relation between Empirical Legal Studies (ELS) and L\&S. The article departs from the observation that ELS, understood as an initiative that emerged in American law schools in the early 2000s, has been quite successful in generating more attention to the empirical study of law and legal institutions in law schools, both in- and outside the US. In the early years of its existence, L\&S - another important site for the empirical study of law and legal institutions also had its center of gravity inside the law schools. But over time, it shifted towards the social sciences. This article discusses how that happened, and more in general explains how L\&S became ever more diverse in terms of substance, theory and methods.
\end{abstract}

\section{Introduction}

In 2001, Theodore Eisenberg published a review on the emergence of Empirical Legal Studies (ELS), in which he explained how ELS brought a great deal of empirical scholarship on law and legal institutions back into the law schools. ${ }^{1}$ He observed, 'much of the empirical study of law was segmented across varying disciplines with no center [...] The growth of ELS has given law-related empirical scholarship a center, albeit a diffuse center, in law schools'.2 Eisenberg's observation, regarding the segmentation of law-related empirical scholarship, prompts questions about the pre-ELS era. Why was empirical scholarship on law and legal institutions segmented across disciplines? And has it always been this way?

In answering these questions, this article focuses on the evolution of the Law and Society Movement (L\&S) - an important alternative site for the empirical study of law and legal institutions. The article notes that L\&S, at the time of its emergence, also had its centre of gravity inside the law schools. Over time, that centre gradually

* Daniel Blocq is assistant professor at Leiden Law School. Maartje van der Woude is professor at Leiden Law School. Authors are both affiliated with the Van Vollenhoven Institute for Law, Governance \& Society (VVI) and contributed equally to this manuscript.

1. T. Eisenberg, The Origins, Nature, and Promises of Empirical Legal Studies and a Response to Concerns' 5 University of Illinois Law Review (2011) 171.

2. Eisenberg, above n. 1, at 1719 moved away from law schools towards the social sciences. We explain why the shift occurred and how the movement became ever more diverse in terms of substance, theory and methods.

But the article does not stop there. In effectively contributing to debates about the relationship between ELS and $L \& S$, the paper observes that $L \& S$, in spite of its enormous breadth and diversity, has not been without boundaries or direction. In the article, we identify a particular set of traits that characterise L\&S. Consideration of these traits is useful not only for deepening our understanding of L\&S but also for reflecting on the nature and character of ELS, in the Netherlands and beyond.

Two words of caution are in order at this point. First, we do not aim to provide a complete overview of the evolution of the L\&S. Instead, relying on a combination of past reviews, presidential addresses ${ }^{3}$ and interviews with leading L\&S scholars, ${ }^{4}$ we highlight several processes and turning points that contributed to the nature of L\&S. Second, in reflecting on the evolution of L\&S, we focus on developments in the United States. We acknowledge the fact that very valuable socio-legal work has occurred outside the United States. But we also observe that North American scholarship has been dominant in the evolution of the L\&S.

Finally, there is a need for clarification of the label ELS, or at least how it is understood in the context of this article. We understand ELS as a movement that emerged in American law schools in the early 2000s. Like the L\&S, ELS is interdisciplinary in nature. But as several scholars have noted, unlike $L \& S$, the centre of gravity of ELS lies chiefly within the law schools. ${ }^{5}$ Furthermore, ELS is often characterised as a movement

3. Presidential addresses of the Law \& Society Association (LSA) do not perfectly reflect the field. Sometimes the 'projects' that presidents imagine are not in line with the 'practice' of Law-and-Society scholarship. See R.L. Abel, 'Law and Society: Project and Practice', 6 Annual Review of Law and Social Science (2010) 1, at 5. That said, we also observe that the selection of a president with a specific profile and at a particular point in time - partly - reflects the interests of law-and-society members at that moment. Furthermore, we notice that law-and-society presidents use their knowledge of the field to shape their addresses. The addresses thus offer a glimpse into wider debates in L\&S over time.

4. These interviews have been conducted by UC Berkeley's Center for the Study of Law \& Society, and are available at: https://www.law.berkeley. edu/centers/center-for-the-study-of-law-society/conversations-in-lawand-society/(accessed on July 18, 2018).

5. Eisenberg, above n. 1; see also M. Suchman and E. Mertz, 'Towards a New Legal Empiricism: Empirical Legal Studies and New Legal Realism', 6 Annual Review of Law and Social Science (2010) 555, at 556. 
with a preference for positivist and quantitative research. ${ }^{6}$

Outside the United States, ELS sometimes seems to be defined more broadly, to incorporate all empirical research conducted on law and legal institutions. This broader definition allows for a diverse set of scholars to be brought under a single umbrella. It is inclusive and helps connect researchers. But to make sense of the different approaches to empirical scholarship, a narrower definition of ELS, like the one adopted in this article, can be useful. Such a definition enables identification of commonalities and differences across the field. Identification of these properties can in turn help us advance empirical research on law and legal institutions as a whole.

\section{Origins}

Law and Society shares its intellectual roots with ELS. Both movements can be traced back to the beginning of the twentieth century when legal scholars in Europe and the United States started to move beyond a purely doctrinal study of law. In Europe, we observe how collaboration between legal scholars and social scientists intensified as a result of the expansion of the administrative state. This collaboration served to increase the effectiveness and efficiency of policy and law, both instruments of social control. ${ }^{7}$

In the United States, where Sociological Jurisprudence and Legal Realism gained traction, legal scholars also developed an interest in the impact of law. But in doing so, they mainly focused on the effect of judicial decisions. ${ }^{8}$ In addition, legal realists wanted to better understand the human determinants of court rulings. Contrary to the belief that these decisions were the outcome of mechanical application of legal principles to actual cases, legal realists argued that judicial decisions were made by human beings who were themselves subject to all kinds of norms, beliefs and emotions that affected the outcome of particular cases. ${ }^{9}$

6. Theodore Eisenberg, one of the founders of ELS, explained how ELS 'helps the study of law and the legal system to join part of a larger probabilistic revolution [...] ELS employs a methodology that is usually, but not always, the methodology of statistical analysis'. See Eisenberg, above n. 1, at 1719, emphasis added. See also E. Chambliss, 'When do Facts Persuade? Some Thoughts on the Market for "Empirical Legal Studies"', 71 Law and Contemporary Problems (2008) 17, at 24; Suchman and Mertz, above n. 5, at 558

7. M. M. Feeley, 'Three Voices of Socio-Legal Studies', 35 Israel Law Review (2001) 175, at 177-78.

8. N.E.H. Hull, 'Reconstructing the Origins of Realistic Jurisprudence: A Prequel to the Llewellyn-Pound Exchange over Legal Realism', 38 Duke Law Journal (1989), 1302, at 1305-08; B. Tamanaha, 'A Vision of Social-Legal Change: Rescuing Ehrlich from “Living Law"', 36 Law and Social Inquiry (2011) 197, at 303, 305-8.

9. E. White, 'From Sociological Jurisprudence to Realism: Jurisprudence and Social Change in Early Twentieth-Century America', 58 Virginia Law Review (1972) 999; see also B. Leiter, 'American Legal Realism', in M.P. Golding and W.A. Edmundson (eds.), The Blackwell Guide to the Philosophy of Law and Legal Theory (2005) 50; J. Skolnick, 'The Sociol-
Legal Realism influenced legal education and had an impact on debates in legal theory. Yet its impact on American jurisprudence waned after World War II. In the early 1960s, some scholars started to demonstrate renewed interest in the study of law and society and set up the Law and Society Association (LSA) in 1964. The Association, its annual meeting, and its flagship journal - the Law \& Society Review, launched in 1966 allowed for further and 'routinized intellectual exchange' on questions related to the interaction between law and society. ${ }^{10}$ Four factors appear to have contributed to the renewed interest in law and society and the establishment of the LSA: (a) heightened respect for social sciences; (b) the civil rights movement and the war on poverty; (c) funding opportunities; and (d) an awareness that law-on-the-books was not the same as law-in-action.

Increasing respect for the social sciences surfaced after World War II. Indeed, '[b]y the end of World War II, the social sciences had become a respectable third wing of U.S. higher education'.11 Advances in survey research, many of which occurred during the war, had allowed the social sciences to further position themselves as an enterprise similar to the physical sciences. In searching for universal behavioural laws or regularities, social science increased its standing and became an important instrument for policymaking. ${ }^{12}$

The link between social science and policy was also appealing to many of the early members of the L\&S who were committed to addressing societal problems most notably, problems related to the civil rights movement, the war on poverty, and crime. ${ }^{13}$ From the perspective of legal scholars, collaboration with the social sciences allowed for sounder policy and judicial decision-making. From the perspective of social scientists, attention to law and policy was important for the definition of meaningful questions and for the employment of research output in useful ways. ${ }^{14}$

The actualisation of these normative commitments was facilitated by unprecedented institutional opportunities. $^{15}$ The Russell Sage Foundation, the Walter E. Meyer Research Institute, the Ford Foundation and the American Bar Foundation stimulated and funded entire research centres and other new research initiatives. Influential hubs for law-and-society research,

ogy of Law in America: Overview and Trends', 13 Social Problems (1965) 4, at 7.

10. F.J. Levine, 'Goose Bumps and "The Search for Signs of Intelligent Life" in Sociolegal Studies: After Twenty-five Years', 24 Law and Society Review (1990) 7, at 10.

11. S.S. Silbey, 'Law and Society Movement', in H.M. Kritzer (ed.), Legal Systems of the World: A Political, Social and Cultural Encyclopedia (2002) 860, at 861.

12. B. Garth and J. Sterling, 'From Legal Realism to Law and Society: Reshaping Law for the Last Stages of the Social Activist State', 32 Law and Society Review (1998) 409, at 412.

13. Abel, above n. 3 , at 3

14. See generally Garth and Sterling, above n. 12

15. A more opportunistic reading of this episode suggests that some of the early law-and-society scholars were drawn into the movement in part because of the openings that emerged. See Garth and Sterling, above n. 12 . 
which emphasised interdisciplinary training and exchange, emerged in Berkeley, Denver, Northwestern, Yale and Wisconsin. ${ }^{16}$

Several leading L\&S scholars who were interviewed for the Conversations in Lam \& Society lecture series (CiL\&S), organised and published by University of California, Berkeley's Center for the Study of Law \& Society, also signalled frustration with contemporaneous scholarship in law schools. Lawrence Friedman and Joseph Gusfield argued that the study of black-letterlaw was too limited, partly in light of discrepancies between 'what the law said and what people were doing'. Laura Nader pointed out that she 'felt lonely in the law schools'. And Steward Macaulay observed that there was a need to make law schools 'a more critical place'.

\section{Evolution}

In the early years of the L\&S, collegial relations existed between lawyers and social scientists. Tensions were nonetheless present. 'Social scientists and lawyers were at times allies, but they also competed to define and to gain ascendancy over the new social expertise'. ${ }^{17}$ In the 1970 s, concerns of legal scholars started to dominate the debate. At the time, 'the center of gravity of the field moved toward law, leaving the social science disciplines for the most part outside' ${ }^{18}$ Rita James Simon, one of the early members of the LSA board, similarly explained that social scientists 'were still considered handmaidens and sort of technicians that had to supply just very technical answers to legal scholars who would then (1) frame the problem and (2) analyze what the data really meant' ${ }^{19}$

\subsection{Gap Studies}

The central role of gap studies in early law-and-society scholarship was illustrative of the dominance of legal concerns during the 1960 s and 1970 s. $^{20}$ Building on legal realism, many law-and-society scholars focused on the identification and understanding of gaps between law-on-the-books and law-in-action. ${ }^{21}$ This focus was importantly informed by the legal - not social science assumption that law-on-the-books and law-in-action are generally aligned. ${ }^{22}$ Until today, scholars both within and outside L\&S associate law-and-society research with the study of law-in-action. ${ }^{23}$ To illustrate, Macaulay's renowned article on the (non)use of law between

16. Garth and Sterling, above n. 12 .

17. Garth and Sterling, above n. 12, at 412

18. Garth and Sterling, above n. 12, at 409, emphasis added.

19. Quoted in Abel, above n. 3, at 3; cf. Feeley, above n. 7, at 184.

20. R.L. Abel, 'Law Books and Books About Law', 26 Stanford Law Review (1973) 175; Feeley, above n. 7

21. J.B. Gould and S. Barclay, 'Mind the Gap: The Place of Gap Studies in Sociolegal Scholarship', 8 Annual Review of Law and Social Science (2012) 323, at 324-25.

22. Abel, above n. 20, at 185-86.

23. e.g., S. Macaulay, L. Friedman and E. Mertz, Law in Action: A SocioLegal Reader (2007). contract parties - a classical gap study - is frequently used as an example of law-and-society research. ${ }^{24}$

The popularity of gap studies, in the early years of the $\mathrm{L} \& \mathrm{~S}$, also emerged from desires for social engineering. Law played an important role in that scheme; law helped the state realise its engineering objectives. ${ }^{25}$ But sometimes, law did not realise those objectives. Evaluation in the form of 'legal policy research' was then called for. ${ }^{26}$ But there were also other forms of gap studies, including research that focused on the manifestation of unintended (side)-effects of law. ${ }^{27}$

In the mid-1970s, critiques on gap studies slowly started to emerge from within L\&S itself. One of the staunchest critics, Richard Abel, argued that the central assumption underlying gap studies - the assumption that social behaviour is commonly in line with legal prescripts was problematic. He observed, 'Why should we expect harmony between law and behavior rather than some other relationship - dissonance, for instance, or a purely accidental conjunction? ${ }^{28}$ Abel reasoned that the assumption of harmony made sense in an era in which '[1] egislation [still] expressed and clarified values already immanent in the society [and when] adjudication merely reasserted the values enunciated by previous judges' ${ }^{29}$ But during a time in which 'the actions of those who do govern must be seen as making a difference, a difference phrased in terms of the realization of goals, not just the expression of values', the assumption was less obvious. ${ }^{30}$ In an interview for Berkley's Conversations in Lam and Society, Susan Silbey also argued against gap studies. But she did so for a different reason. Where Richard Abel pointed out that a gap between law-on-the-books and law-in-action is common and not surprising - and, therefore, not clearly worth documenting as such - Susan Silbey observed that many citizens do comply with the law, and that scholars should pay more attention to compliance rather than non-compliance. She explained,

We were so preoccupied with the gap that we weren't paying attention to the meaning, we weren't paying attention to what happens except in that gap. And so it seems to me that the turn that had happened in the scholarship was to notice that in fact what things are called and how they are called is part of their effects, not just the behavior. So it was sort of a step aside. By looking at the gap, we were looking at the tails of the distribution. What we needed, the next thing, we needed to look at the hump. Why do most people go along [...] Most of the work following was about the

24. S. Macaulay, 'Non-Contractual Relations in Business: A Preliminary Study', 28 American Sociological Review (1963) 55. In this article, Macaulay explained that business partners generally make little use of legal sanctions in planning commercial exchanges and in solving commercial disputes. Macaulay thus challenged a central assumption of law-on-the-books - the assumption that the law governed these kinds of exchanges and disputes.

25. Feeley, above n. 7, at 178 .

26. Feeley, above n. 7, at 184

27. See also Gould and Barclay, above n. 21.

28. Abel, above n. 20, at 185

29. Abel, above n. 20, at 186

30. Abel, above n. 20, at 186 
meanings system and the circulating narratives and schemers are what encourage the compliance, the conformity or the legitimacy of the law (emphasis added).

These and other critiques on gap studies contributed to shifts, from legal concerns to social science concerns, in the $\mathrm{L} \& \mathrm{~S}$.

\subsection{Formal Legal Institutions}

A second way in which the dominance of legal concerns transpired in the early years concerned the main objects of investigation: formal legal institutions. Most research focused on the operation of courts, lawyers, juries and, to a lesser extent, the police. In search of a law-and-society canon, Carol Seron and Susan Silbey tellingly indicate, 'Students of law and society have historically pursued the study of law-in-action in (1) courts, (2) lawyers' offices, (3) juries, (4) regulatory agencies, (5) police work, (6) citizens' interactions with those legal actors and agencies' ${ }^{31}$ In his 1986 presidential address, Stewart Macaulay lamented the preoccupation with legal actors and thus implicitly underlined that focus. $\mathrm{He}$ argued:

My case is very simple: I'll argue that we must look beyond the behavior of judges, lawyers, cops, crooks, and eyewitnesses as well as data concerning how many of what kinds of cases come before the courts. We need to understand the behavior of people who comply with or shade and evade the law. We need to consider when and why people turn to lawyers or use other means of solving problems. We need to understand what conduct by legal officials people will applaud or tolerate. To understand these and other things, we must understand people's knowledge of and attitudes toward the legal system. ${ }^{32}$

\section{Transition}

Critiques by Macaulay, Abel and like-minded scholars from L\&S arguably helped gradually shift the emphasis in research away from the concerns and interests of legal scholars to those of social scientists. But these critiques were not the only sources that triggered change. Transformations of the political landscape and developments in the philosophy of science were equally important.

\subsection{Change in the Political Landscape}

The L\&S emerged at a time in which governance in the United States was undergoing important change. The state was making ever more attempts at controlling and directing the behaviour of its citizens; the state became

31. C. Seron and S.S. Silbey 'Profession, Science and Culture: An Emergent Canon of Law and Society Research', in A. Sarat (ed.), The Blackwell Companion to Law and Society (2004) 30, at 35.

32. S. Macaulay, 'Images of Law in Everyday Life: The Lessons of School, Entertainment, and Spectator Sports', 21 Law and Society Review (1987) 185, at 186, emphasis added. more 'activist', both at the national and at the local level. In this context, law-and-society scholars could play an important role, helping governments develop laws and policies in support of their attempts at social engineering. ${ }^{33}$ Through their work many socio-legal scholars tried to contribute to progressive social change and tackle problems like poverty, drugs and racism. ${ }^{34}$

Under the Reagan- and Bush administrations, the desire to support political leaders changed. Abel explains, 'Eight years of Reagan and four of George H.W. Bush coincided with a major shift in the L\&S project. With conservatives in the White House (and increasingly the federal judiciary), there was less interest than earlier in increasing the efficacy of law'. ${ }^{35}$ Law-and-society scholars, mostly liberal, were critical of the political establishment, and started to emphasise and study the - sometimes - ineffective nature of law and policy. In his widely discussed work The Hollow Hope, Gerald Rosenberg, for instance, showed great scepticism about the possibility for social change through litigation. ${ }^{36}$

\subsection{Developments in the Philosophy of Science}

Along with the changing political landscape we could also observe developments in the philosophy of science: postmodernism and critical legal studies gained ground at the expense of positivism. Looking back at the late 1970s, Michael McCann argued, 'The prevailing mode of inquiry in the early decades was gap studies [...] Then, in the late 1970s, several waves of critical theory [...] began to interrogate the promises of rights in more analytically ambitious ways'. ${ }^{37}$ Lynn Mather similarly observed, 'By the 1980s, law and society critics of positivism raised serious challenges to the [positivist] paradigm and articulated postrealist, interpretive, and constitutive approaches to law'. ${ }^{38}$ And in 1984, David Trubek published an article with the revealing title 'Where the Action is: Critical Legal Studies and Empiricism'.

Critical and postmodern approaches to the empirical study of law and legal institutions were particularly prevalent at the University of Massachusetts, where scholars such as Patricia Ewick, Sally Merry, Austin Sarat, Susan Silbey and Barbara Yngvesson were running the Amherst Seminar on Legal Ideology and Legal Process. The program of the Amherst Seminar stimulated serious reflection on the practice of socio-legal studies. ${ }^{39}$ Members of the seminar called for interpretive work and argued against narrow positivism. Susan Sil-

33. J. Simon, 'Law after Society', 24 Law and Social Inquiry (1999) 143, at 145-46.

34. See also M. Galanter, 'Presidential Address: The Legal Malaise; Or, Justice Observed', 19 Law and Society Review (1985) 537, at 538-39.

35. Abel, above n. 3 , at 8 .

36. G. Rosenberg, The Hollow Hope: Can Courts Bring About Social Change? (1991).

37. M. McCann, 'The Unbearable Lightness of Rights: On Sociolegal Inquiry in the Global Era', 48 Law and Society Review (2014) 245, at, 246.

38. L. Mather, 'Reflections on the Reach of Law (and Society) Post 9/11: an American Superhero?', 37 Law and Society Review (2003) 263.

39. See for example C. Harrington and B. Yngvesson, 'Interpretive Sociolegal Research', 15 Law and Social Inquiry (1990) 135; D. Trubek and J. Esser, 'Critical Empiricism in American Legal Studies: Paradox, Program, or Pandora's Box?', 14 Law and Social Inquiry (1989) 3. 
bey and Austin Sarat furthermore argued, 'At the same time that we have been insisting on bringing sociology to law, we have done less well attending to the forces that frame our descriptions of legal institutions and their environments. We have not done very well at promoting a sociology of the sociology of law'. 40

During these years, in which the Amherst Seminar was rather dominant in law-and-society research, many studies on legal discourse and legal ideology emerged. ${ }^{41}$ Furthermore, research on interpretive action and legal consciousness flourished. ${ }^{42}$

\section{The 'Big Tent'}

By the early nineties, L\&S had transformed into an interdisciplinary and methodologically eclectic movement - sometimes referred to as a pluralistic association or a 'big tent', ${ }^{43}$ which 'is getting bigger all the time'. ${ }^{44}$ It is clear that there are different opinions with regard to the size of the LSA tent. In discussing the values of the LSA, Howard Erlanger illustrated the eclecticism. After asking himself, 'What are the values that characterize the LSA?' he explained:

We are committed to each other and to the development of the field, even though we are not always sure what 'the field' is. We are a community that is open to new theories, methods, and substantive topics. And we are a community that seeks to be welcoming to new scholars and to those who aren't the predominantly white, male, U.S.-based scholars who founded LSA. Although we may not always get it right and more work remains to be done, I believe that the history of LSA as an institution is the history of a commitment to these values. ${ }^{45}$

Many scholars within the L\&S indeed appear to have embraced the inclusiveness. ${ }^{46}$ Lynn Mather, for instance, also observed, 'A strength of law and society has been its inclusivity and openness to new perspectives, whether disciplinary, theoretical or methodologi-

40. Silbey and Sarat, 'Critical Traditions in Law and Society Research', 21 Law and Society Review (1987) 165, at 165-66.

41. See for example J. Conley and W. O'Barr, Rules Versus Relationships: The Ethnography of Legal Discourse (1990); L. Mather and B. Yngvesson, 'Language, Audience, and the Transformation of Disputes', 15 Law and Society Review (1980-81) 775; S.E. Merry, Getting Justice and Getting Even: Legal Consciousness among Working Class Americans (1990); A. Sarat and W.L.F. Felstiner, 'Law and Strategy in the Divorce Lawyer's Office', 20 Law and Society Review (1986) 93.

42. See generally S.S. Silbey, 'After Legal Consciousness', 1 Annual Review of Law and Social Science (2005) 323.

43. H.S. Erlanger, 'Organizations, Institutions, and the Story of Shmuel: Reflections on the 40th Anniversary of the Law and Society Association', 39 Law and Society Review (2005) 1

44. M. Friedman, 'Coming of Age: Law and Society Enters an Exclusive Club', 1 Annual Review of Law and Social Science (2005) 1, at 2.

45. Erlanger, above n. 43, at 4

46. See D.M. Engel, 'Making Connections: Law and Society Researchers and Their Subjects', 33 Law and Society Review (1999) 3; Erlanger, above n. 43, at 6; Galanter, above n. 34, at 537-38. cal' ${ }^{47}$ The many presidential calls for further expansion through issues such as inclusion of international scholars and consideration of issues pertinent to those scholars, ${ }^{48}$ through attention to new themes like violence, ${ }^{49}$ and by calling for more activist and policy-oriented work exemplify the appreciation of inclusiveness. ${ }^{50}$

As mentioned, not all law-and-society scholars have appreciated the increasing breadth or inclusiveness of the movement. To some it has been a cause for concern. In the same address in which Erlanger celebrated diversity, he also observed, 'All this is not to say that valuing diversity in scholarly style is cost-free [...] we have valued breadth over focus and parsimony [...] To the extent that law and society seeks to be an independent discipline with its own theory and methods, there will be pressure to define a much more focused core, and to set boundaries. ${ }^{51}$ In a review of Kitty Calavita's Invitation to Lam E Society: An Introduction to the Study of Real Lam ${ }^{52}$ Austin Sarat bemoaned the state of affairs, writing

In the late $1980 \mathrm{~s}$, I enthusiastically participated in a set of meta-debates about the nature of law and society as an intellectual endeavour and about the directions that law and society research might most profitably take [...] At that time, it still seemed meaningful to talk about a law and society paradigm and to refer to law and society as a 'movement.' Two decades later it no longer seems appropriate to do so. Even as the field has flourished, the law and society paradigm has decomposed. What was a paradigm is now what Kitty Calavita [...] rightly refers to as a 'perspective.' What was a movement has become what she refers to as a 'mentality'. 53

The increasingly eclectic nature of the L\&S has spurred the emergence of new factions, associations and journals. Law-and-society scholars with a stronger interpretivist bent started the Association for the Study of Law, Culture and Humanities in 1998, and launched the journal Lam, Culture and Humanities in 2005. Some lawand-society scholars with a preference for positivist and quantitative work co-initiated or jumped on the bandwagon of ELS. These initiatives have not necessarily led to an abandonment of the LSA. Instead, we find eminent scholars, such as Valerie Hans and Austin Sarat, taking up positions of leadership in different associations.

47. Mather, above n. 38 , at 278 .

48. Mather, above n. 38.

49. C.J. Greenhouse, 'Tuning to a Key of Gladness', 32 Law and Society Review (1998) 1.

50. C. Seron, 'The Two Faces of Law and Inequality: From Critique to the Promise of Situated, Pragmatic Policy', 50 Law and Society Review (2016) 9.

51. Erlanger, above n. 43 , at 8 .

52. K. Calavita, Invitation to Law and Society: An Introduction to the Study of Real Law (2010).

53. A. Sarat, 'From Movement to Mentality, From Paradigm to Perspective, From Action to Performance: Law and Society at Mid-Life', 39 Law and Social Inquiry (2014) 217, at 218. 


\section{Characteristic Traits}

In spite of its diversity, $L \& S$ is not without direction. The movement has several characteristic traits, some of which are precisely about diversity - a conscious and very deliberate diversity. We discuss three traits below. A fourth trait, involving the space that $L \& S$ offers for both positivist and interpretivist work, emerged in the previous discussion on developments in the philosophy of science.

\subsection{State Law, Non-State Law and Informal Rules}

Attention to state law and formal legal institutions has always been central to law-and-society scholarship. But over time, scholarly interest in non-state law increased. To be sure, non-state law was a principal object of investigation in legal anthropology already before the organisation of the LSA. But in the early years, legal anthropologists were not as visible and influential in the formal organisation of the $L \& S$ as they would later become..$^{54}$

The increasing prominence of legal anthropologists in the L\&S, and the expansion of research on legal pluralism from colonial contexts - old legal pluralism - to the developing world - new legal pluralism - paved the way for or implied a broader approach to the study of law and legal institutions. ${ }^{55}$ In her 1989 presidential address, Felice Levine also reflected on the issue, writing:

The centrality of law has always been an issue of tension in sociolegal studies [...] In order to understand law, our scholarly work must not only focus on isolating and explaining patterns of departure from law but also look at law in different locales. Coming to understand law with a little ' 1 ' in everyday lives is consistent with calls that date back to the 1960s and early 1970s [...] While the call is not new, it has been endorsed more readily in principle than in practice. One explanation of this ambivalence may flow from the influence of legal scholarship and the apprehension that a broader definition of boundaries might strip our incipient field of a field..$^{56}$

Despite initial concerns about attention to law with a little ' 1 ', non-state law and informal rules have taken up a prominent role in contemporary law-and-society scholarship. ${ }^{57}$ The Fournal of Legal Pluralism and Unofficial

54. See also Eisenberg, above n. 1, at 1716

55. S.E. Merry, 'Legal Pluralism', 22 Law and Society Review (1988) 869.

56. Levine, above n. 10, at 20-21.

57. As Munger observes, 'Faithfulness to insight has led law and society scholars away from studies of liberal legal institutions on their own terms and toward highly contextualized studies of law in organizations, in communities, in families, in everyday life. Powered by a critique of law that decentres or deconstructs the authority of law, law and society research locates the role of law in the very fabric of social relationships, consciousness and identities.' See F. Munger, 'Presidential Address: Inquiry and Activism in Law and Society', 35 Law and Society Review (2001) 7, at 10-11.
Law and Sally Falk Moore's widely cited work on semiautonomous social fields testify of the role. ${ }^{58}$

Another arena where we observe an increase in attention to non-state law is regulation. Past research has shown that industries sometimes regulate themselves. ${ }^{59}$ This self-regulation implies an increase in non-state laws in companies - an increase that has in turn spurred research on enforcement and compliance with these non-state laws (Ibid.).

\subsection{Social Justice and Social Change}

In addition to consideration of non-state law, we also observe that social justice became a more central concern. Where the early presidential addresses focused on formal legal institutions ${ }^{60}$ or images of state law, ${ }^{61}$ we find that more recent addresses tend to focus on questions of justice, ${ }^{62}$ rights, ${ }^{63}$ oppression and inequality. ${ }^{64}$ In these addresses, state law and formal legal institutions seem to take a back seat. An (implicit) assumption is that these issues - state law and formal legal institutions - are at the service of justice and quality. And that warrants a focus on justice, rights, oppression and (in)equality as such. In that vein, Michael McCann reminds us that attention to 'rights' is not new within the L\&S, writing

Perhaps no topic, short of law itself, has been more central to the sociolegal legacy of scholarly inquiry than that of rights. It is worth remembering that Law and Society as an intellectual movement and professional association was born in the era of the U.S. civil rights movement. The first volume of the Law \& Society Review was published in 1966, when the ink was still drying on the 1964 Civil Rights Act and 1965 Voting Rights Act. In fact, the first special issue of LSR in 1967 (Vol. 2, no. 1) was on school desegregation in the United States. ${ }^{65}$

But in those early years, we also observe a great deal of work that tries to focus on state law and formal legal institutions without putting much emphasis on the fairness or justness of those institutions. To illustrate, in his 1982 presidential address, Herbert Jacob emphasised the need for effectiveness. He argued, 'To understand

58. Moore 1973

59. See for example R. Cheit, Setting Safety Standards: Regulation in the Public and Private Sectors (1990); J. Rees, Reforming the Workplace: A Study of Self-Regulation in Occupational Safety (1988).

60. See for example Galanter 1985; H. Jacob, 'Presidential Address: Trial Courts in the United States: The Travails of Exploration', 17 Law and Society Review 407 (1983))

61. Macaulay, above n. 32.

62. S.S. Silbey, "'Let Them Eat Cake": Globalization, Modern Colonialism, and the Possibilities of Justice', 31 Law and Society Review (1997) 207.

63. McCann, above n. 37, at 245.

64. R. Lempert, 'A Personal Odyssey Toward a Theme: Race and Equality in the United States: 1948-2009', 44 Law and Society Review (2010) 431.

65. McCann, above n. 37, at 246. Frank Munger also pointed out, 'The inception of the law and society field in North America, and in many other societies, was motivated by a belief in the simple proposition that law should stand for equality and for justice'. See Munger, above n. 57, at 7 . 
courts is rewarding in its own right, and if we understand them more fully, we might be able to help design them to do their work more effectively.' (1983: 419, emphasis added). The implicit assumption here is that the objectives underlying the organisation of formal legal institutions - objectives set by legislators and policymakers - are unproblematic. And therefore attention to effectiveness is justified. As law-and-society scholars started to become more critical of government over time, questions of effectiveness moved to the background. Indeed, there are no references to effectiveness in the more recent presidential addresses.

Law-and-society's commitment to social justice also connects to a concern for progressive social change. This concern does not only manifest itself in research that is informed by questions related to justice and equality. It also transpires in calls for policy-oriented research and engagement with activism, ${ }^{66}$ that is, calls for contributing to the resolution of (in)justices identified in research. The renowned debate between Joel Handler and Sally Engle Merry illustrates the concern for progressive social change that binds many - but not all - law-and-society members. ${ }^{67}$ In his presidential address, Handler lamented the increasing dominance of postmodernism in (law-and-society) research. ${ }^{68}$ Sally Merry offered a rejoinder in the presidential address that came right after. ${ }^{69}$ Interestingly, the debate was not about the ontological or epistemological value of postmodernism per se. Instead, it focused on 'the value of postmodernism for transformative politics' ${ }^{70}$

\subsection{Global North and Global South}

Another important characteristic of the L\&S concerns its international orientation. While North American scholars have been dominant inside the LSA - all past presidents have been employed by universities in the United States - L\&S scholarship shows considerable geographical diversity. In 1968, the Lam E Society Reviem (LSR), the flagship journal of the LSA, devoted a special issue to 'Lawyers in Developing Societies with Particular Reference to India'. In the 1970s, we find work on excuses to criminal responsibility in East Afri$\mathrm{ca}^{71}$ deviance in Singapore, ${ }^{72}$ the legal revolution in Turkey, ${ }^{73}$ and political leadership and legal change in Mexico. ${ }^{74}$ To be sure, most manuscripts in $L S R$ focused on American law and legal institutions in the 1970s. But

66. (Seron 2016); See Munger, above n. 57.

67. For an exception see S. Liu, 'Law's Social Forms: A Powerless Approach to the Sociology of Law', 40 Law and Social Inquiry (2015) 1.

68. J.F. Handler, 'Postmodernism, Protest, and the New Social Movements', 26 Law and Society Review (1992) 697

69. S.E. Merry, 'Resistance and the Cultural Power of Law', 29 Law and Society Review (1995) 11.

70. Handler, above n. 68, at 697; see also Merry, above n. 69, at 11.

71. L. Kato, 'Functional Psychosis and Witchcraft Fears: Excuses to Criminal Responsibility in East Africa', 4 Law and Society Review (1970) 385.

72. G. Count-van Manen, 'A Deviant Case of Deviance: Singapore', 5 Law and Society Review (1971) 389.

73. J. Starr and J. Pool, 'The Impact of a Legal Revolution in Rural Turkey', 8 Law and Society Review (1974) 533.

74. J.F. Collier, 'Political Leadership and Legal Change in Zinacantan', 11 Law and Society Review (1976) 131. as the above examples and other $L S R$ articles from this period show, we observe a genuine interest in questions arising in the Global South, already in the early days of the L\&S. Work of leading scholars within the L\&S such as Sally Falke Moore, Sally Engle Merry, John and Jean Comaroff and also Marc Galanter obviously illustrate this early interest in the Global South.

In an interview for Berkeley's Conversations in Law E Society, Laura Nader discussed the relevance of such a global perspective and the need for comparison. She argued, a bit provocatively, 'I realized you had to do comparison. You can't just look at one place. That's the problem with people who study American law [....] Or the way Europeans look at law. They are very ethnocentric.' And that ethnocentrism creates obstacles to a full understanding of the operation of law and legal institutions inside the societies that we as scholars respectively live in. She observed, 'You study the Zapatec, and of course you look in the mirror. That whole notion of using what you find abroad to look at your own society permeates my work.' That notion was probably important to many legal anthropologists. But it seems to have also appealed to political scientists within $L \& S$, many of whom currently study socio-legal questions in the Global South.

\section{Conclusion}

In this article we have offered reflections on the evolution of law-and-society research. Through these reflections we made a modest attempt to explain how the L\&S changed from a field in which concerns of legal scholars and practitioners were prevalent to one in which social scientists seem to have become more influential. Presidential addresses and reviews of the L\&S have furthermore shown that the field has become very interdisciplinary and eclectic in terms of research methodologies. This diversity has been celebrated by some and bemoaned by others.

The development towards ever more inclusiveness may result in at least two outcomes for Law and Society. On the one hand, we can imagine L\&S turning into a platform, rather than a unified movement. That platform would be made up of different voices and audiences. ${ }^{75}$ The emergence of sub-fields within $L \& S$ would, in this scenario, be appreciated rather than seen as problematic. The field of L\&S would continue to grow and flourish, without people worrying too much about what this means for the central scope, core and message of the scholarship coming out of it. In a second scenario, L\&S would be more sceptical of the diversity. It would strive

75. Malcolm Feeley already observed in 2001 how socio-legal studies 'speaks with at least three voices [...] It speaks as policy analysis, a handmaiden to law. It also speaks in the traditional language of the social sciences. Thirdly, it may be gaining a voice of its own, reflecting a belief that law is a distinct form of ordering that merits its own position among the scholarly disciplines, separate from both scholarly fields and the professional concerns of law'. See Feeley, above n. 7, at 175). 
for a common core and a set of relatively well-defined boundaries of the field. By doing so, L\&S could perhaps play a more prominent and active role in deepening scholarship. At this stage, it is hard to speculate on the likelihood of either one of these, and perhaps other, scenarios.

We finally hope that this article can contribute to current discussions, in the Netherlands and beyond, about the development of ELS broadly defined, that is, all scholarship focusing on the study of law and legal institutions. By offering insights on the character of $L \& S$, we anticipate a better understanding of $L \& S$, and thus a debate on the relationship between ELS and L\&S that rests on sound assumptions about L\&S. We specifically hope that this understanding of L\&S will bring scholars, engaged in the empirical study of law and legal institutions, further together. It seems to us that a broad definition of ELS, which seems to be rather current in the Netherlands, encompasses a great deal of L\&S research. The characteristic traits of L\&S, identified in this article, may finally help deepen discussions on the relationship between L\&S and ELS. These discussions have, all too often, revolved around dichotomies such as quantitative versus qualitative or applied versus more fundamental. Serious reflection on the L\&S traits may enrich - ELS - debates about empirical research on law and legal institutions, bring people on opposite sides of the methodological spectrum together, and bring empirical scholarship to the next level, both within and outside the Netherlands. 